\title{
Analysis of the flagellin (hag) gene of alkalophilic Bacillus sp. C-125
}

\author{
Yoh-ichiro Sakamoto, $†$ Katharine J. Sutherland, Jin Tamaoka, Tetsuo Kobayashi, \\ TOSHIAKI KUDO* and KOKI HORIKOSHI
}

The RIKEN Institute and JRDC, Hirosawa 2-1, Wako-shi, Saitama, 351-01, Japan

(Received 17 March 1992; accepted 23 June 1992)

\begin{abstract}
Motility of the alkalophilic Bacillus sp. C-125, a flagellate bacterium, was demonstrated to be $\mathrm{Na}^{+}$- and pHdependent. Flagellin protein from this strain was purified to homogeneity and the $\mathrm{N}$-terminal sequence determined. Using the hag gene of Bacillus subtilis as a probe, the hag gene of Bacillus sp. C-125 was identified and cloned into Escherichia coli. Sequencing of this hag gene revealed that it encodes a protein of 272 amino acids $\left(M_{\mathrm{r}} 29995\right)$. The predicted $\mathbf{N}$ terminal sequence of this protein was identical to that determined by $\mathrm{N}$-terminal sequencing of the flagellin protein from strain C-125. The alkalophilic Bacillus sp. C-125 flagellin shares homology with other known flagellins in both the $\mathrm{N}$ - and $\mathrm{C}$-terminal regions. The middle portion, however, shows considerable differences, even from that of flagellin from the related species, $B$. subtilis.
\end{abstract}

\section{Introduction}

The flagellar apparatus has been extensively studied in neutrophilic bacteria such as Escherichia coli and Bacillus subtilis and has been shown to be a complex structure composed of a basal body, a hook and a filament. The filament accounts for $98 \%$ of the mass of the organelle and is composed exclusively of flagellin, the product of the hag gene (Iino, 1977; Silverman \& Simon, 1977).

Flagellin plays only a passive role in motility, the mechanical energy for flagellar rotation being generated by a motor in, or associated with, the basal body structure of the organelle (Ridgeway et al., 1977; Dean et al., 1984; Blair \& Berg, 1990). Nevertheless, flagellin has proved a focus of interest due to its self-assembling properties (Asakura et al., 1964; Macnab \& Aizawa, 1984), its method of transport across the cell membrane (Homma et al., 1987; LaVallie \& Stahl, 1989) and other features such as its antigenicity.

The primary amino acid sequences of flagellins from a number of neutrophilic bacteria have been determined (Gill \& Agabian, 1983; Joys, 1985; Wei \& Joys, 1985; Kuwajima et al., 1986; Martin \& Savage, 1988; LaVallie

* Author for correspondence. Tel. 0484 (62) 1111 ext. 3443; fax 0484 (62)4672.

$\dagger$ Present address: Hiratsuka Research Laboratories, Sumitomo Heavy Industries Ltd, Hiratsuka, Japan.

The nucleotide sequence data reported in this paper have been submitted to GenBank and have been assigned the accession number D10063.
\& Stahl, 1989; Mirel \& Chamberlin, 1989). The flagellin of alkalophilic bacteria, being exposed to the alkaline environment in which these organisms live, is likely to show special adaptations to alkaline conditions. In addition, flagellin, unlike other extracellular proteins so far studied, as a polymer is a good model for the study of subunit-subunit interactions under alkaline conditions. However, hitherto, there have been no reports on the flagellin gene of alkalophiles.

We have selected the alkalophilic Bacillus sp. C-125 as a model alkalophile for molecular biological study for the following reasons: (i) it grows well on minimal medium, (ii) genes from this strain are expressed well in E. coli, and (iii) an efficient system for plasmid transformation of this strain is now available (Kudo et al., 1990). In this paper, we report the cloning and sequencing of the hag gene from the alkalophilic Bacillus sp. C-125.

\section{Methods}

Bacterial strains and media. Alkalophilic Bacillus sp. C-125 10596 $\left(\mathrm{Trp}^{-} \mathrm{Ura}^{-} \mathrm{Cm}^{\mathrm{s}}\right.$ ) was isolated in our laboratory (Honda et al., 1985; Kudo et al., 1990). It was grown on Horikoshi-II medium ( $\mathrm{pH} \mathrm{10 \cdot 3)}$ containing $1 \%(\mathrm{w} / \mathrm{v})$ soluble starch, $0.5 \%$ yeast extract, $0.5 \%$ polypeptone, $0 \cdot 1 \% \mathrm{~K}_{2} \mathrm{HPO}_{4}, 0.02 \% \mathrm{MgSO}_{4} .7 \mathrm{H}_{2} \mathrm{O}$, and $1 \% \mathrm{Na}_{2} \mathrm{CO}_{3}$ (sterilized separately). The Bacillus DNA was cloned in E. coli MV1184 (ara $\Delta$ (lac-proAB) rpsL thi ( $\phi 80$ lacZ $\Delta \mathrm{M} 15) \Delta($ srl-recA)306: : Tn 10 (Tet $\left.{ }^{r}\right) \mathrm{F}^{\prime}\left[\right.$ traD36 proAB lacI ${ }^{\mathrm{q}}$ lacZ $\left.\Delta \mathrm{M} 15\right]$ ]). E. coli was grown on $2 \times$ yeast/tryptone medium (Sambrook et al., 1989).

Plasmids, enzymes and chemicals. pUC vectors, restriction endonucleases and $\mathrm{T}_{4}$ DNA ligase were purchased from Takara Shuzo Co. The DIG (digoxigenin) DNA labelling and detection kit was obtained from 
Boehringer Mannheim. Hybond $\mathrm{N}^{+}$and Hybond $\mathrm{N}$ membranes were purchased from Amersham. Sequencing oligonucleotide primers were synthesized on an Applied Biosystems 380B DNA synthesizer. HindIII-digested $\lambda$ HaeIII-digested $\phi X 174$ DNA standards (23130, $9416,6557,4361,2322,2027,1353,1078,872$ and $603 \mathrm{bp}$ ) were purchased from Toyobo. Protein standards, purchased from Pharmacia, consisted of $\alpha$-lactalbumin (14400), soybean trypsin inhibitor $(20100)$, carbonic anhydrase $(30000)$, ovalbumin $(43000)$, bovine serum albumin (67000) and phosphorylase $b(94400)$.

Electron microscopy. Flagellation of alkalophilic Bacillus sp. C-125 was observed by transmission electron microscopy with a JEOL model $200 \mathrm{CX}$ microscope at $100 \mathrm{kV}$ after negative staining with $1 \%(\mathrm{w} / \mathrm{v})$ phosphotungstic acid.

Physical characterization of motility. Swimming speeds were measured using a television monitor attached to a microscope. Alkalophilic Bacillus sp. C-125 was grown aerobically to late exponential phase at $37^{\circ} \mathrm{C}$ in Horikoshi-II medium (pH10.3), collected and washed twice. Cells were resuspended in a $25 \mathrm{~mm}-\mathrm{Tris} / \mathrm{HCl}$ (pH 9.0), $5 \mathrm{~mm}$-glucose solution containing $100 \mathrm{~mm}-\mathrm{NaCl}$ unless indicated otherwise.

Purification of flagellin protein. Flagellin protein of alkalophilic Bacillus sp. C-125 was purified to homogeneity by the method of Martinez (1963). SDS-PAGE was carried out as described by Laemmli (1970).

$N$-terminal sequence of the purified flagellin. The method of Edman \& Henschen (1975) was used, with an Applied Biosystems 477A protein sequencer coupled to a PTH120A analyser.

Amino acid analysis. This was done on an Applied Biosystems PTH120A analyser.

Preparation of genomic DNA. The method of Saito \& Miura (1963) was used.

Preparation of probe DNA. The B. subtilis hag gene used as probe was constructed by PCR using the oligonucleotides 5' ACGTGCCTTAACAACATATT $3^{\prime}$ and $5^{\prime}$ ATGAGGAATGATTAGGAGAT $3^{\prime}$ as primers to regions upstream and downstream of the $B$. subtilis hag gene, respectively (LaVallie \& Stahl, 1989; Mirel \& Chamberlin, 1989).

Southern blot analysis. Genomic DNA $(10 \mu \mathrm{g})$ of alkalophilic Bacillus sp. C-125 was digested with restriction endonucleases, separated on a $1 \%(\mathrm{w} / \mathrm{v})$ agarose gel and then blotted using a vacuum blotter (Pharmacia LKB) on to Hybond $\mathrm{N}^{+}$. Blots were probed with digoxigenin-labelled $B$. subtilis hag gene in a $20 \%(\mathrm{v} / \mathrm{v})$ formamide hybridization solution at $42{ }^{\circ} \mathrm{C}$. Subsequent washing and detection steps were carried out according to instructions provided with the Boehringer Mannheim DIG-detection kit.

Constructing and screening a sub-genomic library. Genomic DNA $(100 \mu \mathrm{g})$ of alkalophilic Bacillus sp. C-125 was digested with the appropriate restriction endonuclease and separated by electrophoresis on a $1 \%(w / v)$ agarose gel. DNA of the desired fragment size was recovered from the agarose by electroelution, treated with phenol/ chloroform and then precipitated with ethanol. The size-selected DNA was cloned into pUC vector in $E$. coli MV1184. Colony blots were prepared according to instructions provided with the Hybond $\mathbf{N}$ membrane and hybridized with digoxigenin-labelled $B$. subtilis hag gene as described above for Southern blot analysis.

$D N A$ sequencing. This was done by the technique of Sanger $e t$ al. (1977) on a Dupont DNA Sequencer using single-stranded pUC as template and a Dupont sequencing kit.

Sequence alignment. Flagellin sequences were aligned using the GENETYX amino acid sequence homology program (Tokyo, Japan).

\section{Results and Discussion}

\section{Characterization of the motility of alkalophilic Bacillus sp. $C-125$}

Alkalophilic Bacillus sp. C-125 is a flagellate bacterium (Fig. 1). Whereas in neutrophilic bacteria flagellar rotation is powered by $\mathrm{H}^{+}$-driven motors, in alkalophiles, apparently because the protonmotive force is too low, rotation is powered by $\mathrm{Na}^{+}$-driven motors (Hirota et al., 1981). The effect of $\mathrm{Na}^{+}$concentration on motility of alkalophilic Bacillus sp. C-125 cells is shown in Fig. 2. Maximum motility was observed at $50 \mathrm{mM}-\mathrm{NaCl}$. When other cations (in the form of $\mathrm{KCl}, \mathrm{LiCl}, \mathrm{NH}_{4} \mathrm{Cl}, \mathrm{RbCl}$, $\mathrm{CsCl}, \mathrm{CaCl}_{2}$ and $\mathrm{MgCl}_{2}$ ) were used in place of $\mathrm{Na}^{+}$no motility was observed. In addition, amiloride, a specific inhibitor of $\mathrm{Na}^{+}$-driven flagellar motors (Sugiyama et al., 1988) inhibited movement of alkalophilic Bacillus sp. C-125 cells at concentrations greater than $1 \mathrm{mM}$. We conclude, therefore, that as in other alkalophiles, the flagellar motor of alkalophilic Bacillus sp. C-125 is driven by $\mathrm{Na}^{+}$.

$\mathrm{pH}$ also affected the motility of alkalophilic Bacillus sp. C-125 cells, with no motility being observed at $\mathrm{pH}$ values less than 7.5. Microscopic observation of cells transferred from alkaline to neutral $\mathrm{pH}$ revealed that cells at the new lower $\mathrm{pH}$ were no longer flagellate (data not shown). This loss of flagella presumably accounts for the loss of motility at $\mathrm{pH}$ values below 7.5. Kamiya \& Asakura (1976) showed that Salmonella flagella displayed a remarkable reversible polymorphism when transferred from neutral $\mathrm{pH}$ to $\mathrm{pH} 4.7$ and lower. It is possible, therefore, that the loss of flagella by alkalophi-

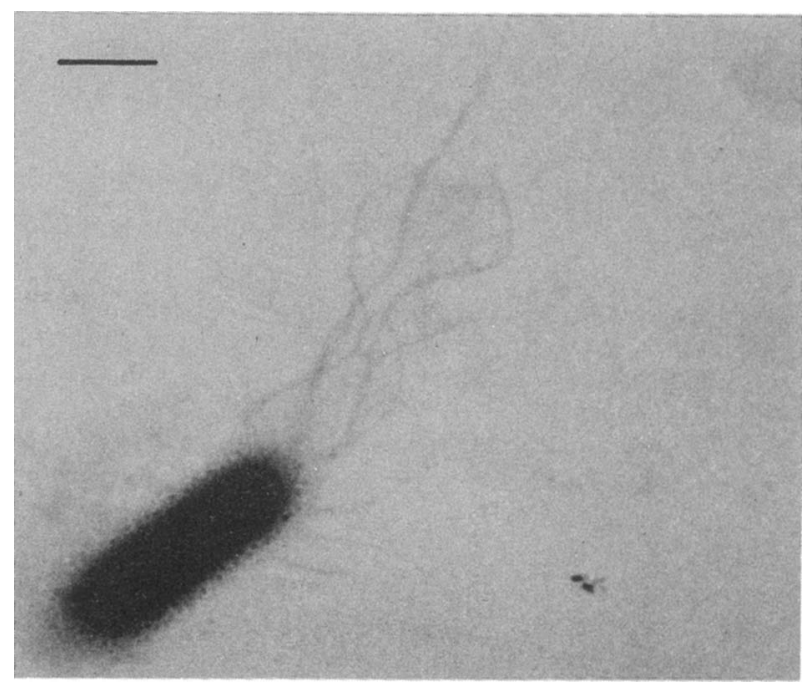

Fig. 1. Electron micrograph of an alkalophilic Bacillus sp. C-125 cell. Bar, $1 \mu \mathrm{m}$. 


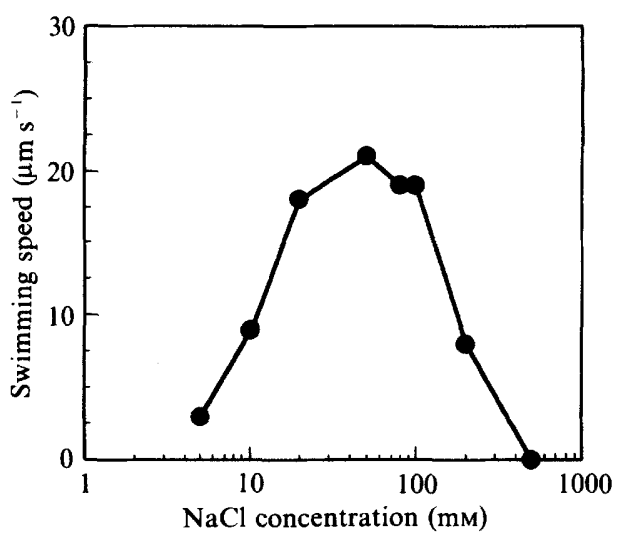

Fig. 2. Effect of $\mathrm{Na}^{+}$concentration on swimming speeds of alkalophilic Bacillus sp. C-125 cells. Data shown are mean values of the swimming speeds of more than 28 cells for each concentration.

lic Bacillus sp. $\mathrm{C}-125$ at $\mathrm{pH}$ values below 7.5 is caused by a polymorphic transition of the flagellin filament which results in the flagella becoming unstable. As yet we have no data to support this speculation; however, it may be possible to test it by observing whether alkalophilic Bacillus sp. C-125 filaments reassociate around seeds of polymerized flagella when the $\mathrm{pH}$ is raised from neutral $\mathrm{pH}$ back to alkaline $\mathrm{pH}$.

\section{The flagellin protein of alkalophilic Bacillus sp. C-125}

Flagellin purified from alkalophilic Bacillus sp. C-125 was pure as judged from the single band obtained on SDS-PAGE (Fig. 3). By comparison with standard proteins the polypeptide $M_{\mathrm{r}}$ of the alkalophilic Bacillus sp. C- 125 flagellin is 31000 .

The N-terminal sequence of the alkalophilic Bacillus sp. C-125 flagellin was determined to be as follows: MetIle-Ile-Asn-His-Asn-Leu-Pro-Ala-Met-.

The amino acid content of the alkalophilic Bacillus sp. C-125 flagellin, as determined by amino acid analysis of the protein, is shown in column 2 of Table 1.

\section{The hag gene of alkalophilic Bacillus sp. C-125}

Fig. 4 shows the result of Southern blot analysis of Bacillus sp. C-125 genomic DNA cut with several endonucleases and probed with the $B$. subtilis hag gene. From this result it was apparent that the alkalophilic Bacillus sp. C-125 hag gene is not carried within a single EcoRI or HindIII fragment. The $1.5 \mathrm{~kb}$ HindIII fragment and the $1.2 \mathrm{~kb} E c o$ RI fragment (Fig. 4) were cloned separately, and subsequently joined at the common EcoRI site. The plasmid containing the complete alkalophilic Bacillus sp. C-125 hag gene was designated pC125Hg.

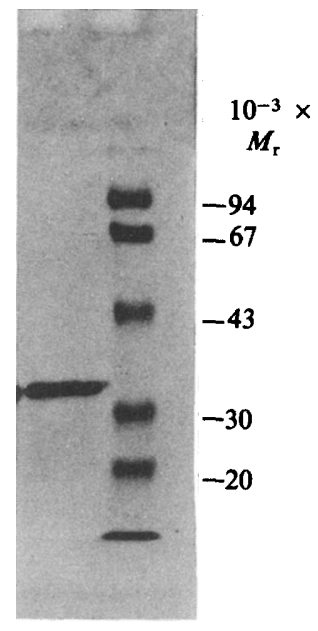

Fig. 3. SDS-PAGE of alkalophilic Bacillus sp. C-125 flagellin. The left lane contains flagellin purified from alkalophilic Bacillus sp. C- 125 cells by the method of Martinez (1963) and the right lane contains standard protein size markers (see Methods).

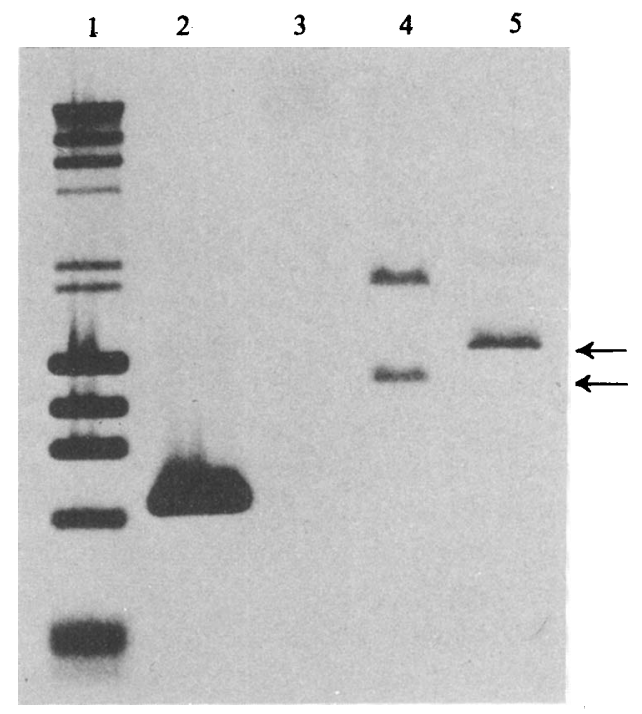

Fig. 4. Southern blot analysis of alkalophilic Bacillus sp. C-125 genomic DNA. Alkalophilic Bacillus sp. C-125 genomic DNA was digested with BamHI (lane 3), EcoRI (lane 4) and HindIII (lane 5). Lanes 1 and 2 contain $\lambda / \phi \times 174$ marker DNA (see Methods) and the $B$. subtilis hag gene PCR product, respectively. The resulting Southern blot was probed with digoxigenin-labelled $B$. subtilis hag gene and digoxigenin-labelled $\lambda / \phi \times 174$ marker DNA. The $1.5 \mathrm{~kb}$ HindIII and $1.2 \mathrm{~kb} E c o \mathrm{RI}$ fragments that were cloned are arrowed.

Sequencing of the inserted DNA fragment on $\mathrm{pC} 125 \mathrm{Hg}$ resulted in the identification of an open reading frame containing the 10 amino acids determined by $\mathrm{N}$-terminal sequencing of the protein (see Fig. 6). This open reading frame is immediately preceded by an ATG codon which we propose acts as the translation initiation 
codon for the hag gene. The $\mathrm{N}$-terminal sequence deduced from the gene sequence is identical to that of the $\mathrm{N}$-terminal sequence determined from the purified flagellin. This indicates that, as observed for other sequenced flagellins, the export of the protein is not directed by an N-terminal signal peptide (Gill \& Agabian, 1983; Kuwajima et al., 1986; LaVallie \& Stahl, 1989).

The open reading frame was sequenced on both DNA strands, using the strategy depicted in Fig. 5. The complete DNA sequence of the alkalophilic Bacillus sp. C-125 hag gene and its immediate 5'- and 3'-flanking regions is presented in Fig. 6. Putative promoter, ribosome-binding site and transcription-termination sequences have been identified (Fig. 6). The promoter sequence resembles that of the $B$. subtilis hag gene, which is thought to be used by the $B$. subtilis sigma-28 RNA polymerase (LaVallie \& Stahl, 1989; Mirel \& Chamberlin, 1989).

The alkalophilic Bacillus sp. C-125 hag gene encodes a protein of 272 amino acids $\left(M_{\mathrm{r}} 29995\right)$. This corresponds to the size determined for the flagellin purified from this strain $\left(M_{\mathrm{r}} 31000\right)$. This is one of the smallest amongst flagellins whose sizes have been determined: Campylobacter flagellins range from $M_{\mathrm{r}} 59500$ to 63800 (Logan et al., 1987); and the E. coli (Kuwajima et al., 1986), the Salmonella typhimurium (SJW1103) (Joys, 1985), the $B$. subtilis (LaVallie \& Stahl, 1989; Mirel \& Chamberlin, 1989), the Roseburia cecicola (Martin \& Savage, 1988) and one of the Caulobacter crescentus (Gill \& Agabian, 1983) flagellin subunits have $M_{\mathrm{r}}$ values of 51172,51000 , 32613,31370 and 29000 , respectively. Trachtenberg \& DeRosier (1988) demonstrated that the $C$. crescentus $\left(M_{\mathrm{r}}\right.$ 29000) flagellin lacks the central stretch of primary amino acids of the $S$. typhimurium flagellin and that this central region corresponds to a molecular domain situated on the outer surface of the $S$. typhimurium flagellar filament. It seems, therefore, that the smallest flagellins lack all or part of an outer molecular domain present in the higher- $M_{\mathrm{r}}$ flagellins.

The amino acid composition of the alkalophilic Bacillus sp. C-125 flagellin, as determined from the sequence, is shown in Table 1, column 3. It compares favourably with the composition determined by direct amino acid analysis of the purified protein (column 2). For comparison, the amino acid compositions of $B$. subtilis and Bacillus firmus RAB flagellins are also included in Table 1. B. firmus RAB flagellin contains few basic amino acids, a feature that has been proposed to make the flagellum more stable at high pH (Guffanti \& Eisenstein, 1983). The alkalophilic Bacillus sp. C-125 flagellin composition, however, does not appear to be significantly different from the $B$. subtilis composition, the lysine content being only slightly lower.

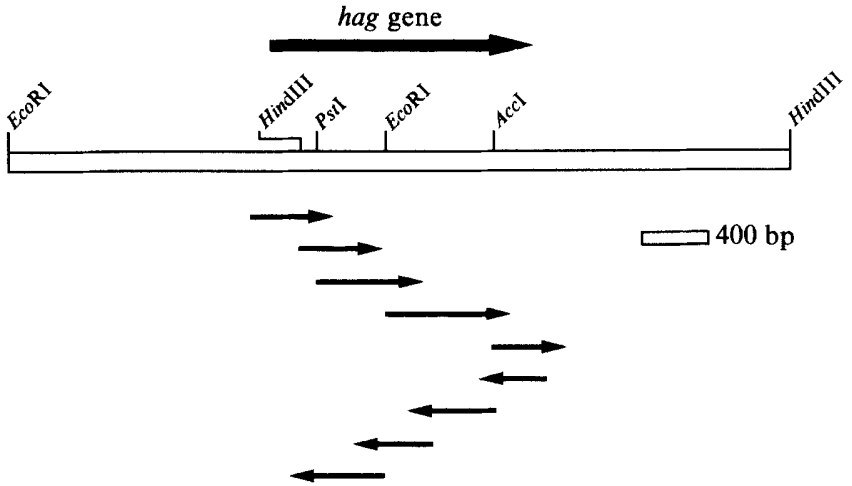

Fig. 5. Restriction map of the DNA region containing the alkalophilic Bacillus sp. C-125 hag gene. The $1.5 \mathrm{~kb}$ HindIII and the $1.2 \mathrm{~kb}$ EcoRI fragments were cloned separately and subsequently joined at the common EcoRI site. The direction and extent of the coding region is indicated by the upper arrow. The lower arrows indicate the direction and extent of the individual sequencing runs.

Table 1. Amino acid compositions of the flagellins of alkalophilic Bacillus sp. C-125 and related bacteria

\begin{tabular}{|c|c|c|c|c|}
\hline \multirow[b]{2}{*}{ Residue } & \multicolumn{4}{|c|}{$\begin{array}{l}\text { No. of residues per molecule } \\
\text { (\% of total in parentheses) }\end{array}$} \\
\hline & $\mathrm{C}-125^{*}$ & C-125† & B. firmus $\mathrm{RAB} \ddagger$ & B. subtilis§ \\
\hline Gly & $16(5 \cdot 8)$ & $12(4 \cdot 4)$ & $41(11 \cdot 7)$ & $19(6 \cdot 3)$ \\
\hline Thr & $14(5 \cdot 1)$ & $14(5 \cdot 2)$ & $43(12 \cdot 3)$ & $18(5.9)$ \\
\hline Ile & $16(5.8)$ & $19(7.0)$ & $21(6 \cdot 0)$ & $22(7 \cdot 2)$ \\
\hline Met & $10(3 \cdot 6)$ & $11(4 \cdot 0)$ & $3(0.9)$ & $8(2 \cdot 6)$ \\
\hline Asp & - & $20(7 \cdot 4)$ & - & $22(7 \cdot 2)$ \\
\hline Arg & $16(5 \cdot 8)$ & $15(5 \cdot 5)$ & $8(2 \cdot 3)$ & $14(4 \cdot 6)$ \\
\hline Phe & $4(1.4)$ & $3(1 \cdot 1)$ & $2(0 \cdot 6)$ & $5(1.6)$ \\
\hline Ala & $33(12 \cdot 0)$ & $33(12 \cdot 1)$ & $84(24 \cdot 0)$ & $39(12.8)$ \\
\hline Val & $11(4 \cdot 0)$ & $11(4 \cdot 0)$ & $13(3 \cdot 7)$ & $14(4 \cdot 6)$ \\
\hline Pro & $3(1 \cdot 1)$ & $2(0.7)$ & $0(0)$ & $2(0.7)$ \\
\hline His & $5(1.8)$ & $6(2 \cdot 2)$ & $3(0 \cdot 9)$ & $4(1 \cdot 3)$ \\
\hline Glu & - & $21(7 \cdot 7)$ & - & $17(5 \cdot 6)$ \\
\hline Asn & - & $21(7 \cdot 7)$ & - & $27(8.9)$ \\
\hline Trp & $0(0)$ & $0(0)$ & $0(0)$ & $0(0)$ \\
\hline Asx & $40(14 \cdot 5)$ & - & $66(18.9)$ & - \\
\hline Glx & $48(17 \cdot 4)$ & - & $34(9 \cdot 7)$ & - \\
\hline Ser & $17(6 \cdot 2)$ & $17(6 \cdot 3)$ & $0(0)$ & $24(7.9)$ \\
\hline Leu & $30(10.9)$ & $30(11 \cdot 0)$ & $23(6 \cdot 5)$ & $29(9 \cdot 5)$ \\
\hline Cys & $0(0)$ & $0(0)$ & $0(0)$ & $0(0)$ \\
\hline Tyr & $2(0 \cdot 7)$ & $1(0 \cdot 4)$ & $2(0 \cdot 6)$ & $1(0 \cdot 3)$ \\
\hline Gln & - & $27(9.9)$ & - & $24(7.9)$ \\
\hline Lys & $11(4 \cdot 0)$ & $9(3 \cdot 3)$ & $7(2 \cdot 0)$ & $15(4 \cdot 9)$ \\
\hline
\end{tabular}

* Obtained by direct amino acid analysis of the purified flagellin.

$†$ Deduced from the hag gene sequence.

$\ddagger$ Cited from Guffanti \& Eisenstein (1983).

$\S$ Derived from data reported by Mirel \& Chamberlin (1989).

\section{Alignment with other known flagellin sequences}

The amino acid sequence of the alkalophilic Bacillus sp. C-125 flagellin was compared to the sequences of $E$. coli (Kuwajima et al., 1986), S. typhimurium (Joys, 1985), B. 
T TAA AAA AGG ACT AAA CTC CTA TGA AAT CGT GTC GAT ATT ATT AAT GTA CCG GAA 55

AAG GAA AAG GCG GCC GAC TTT GTT CCT TTT CGC GGA TTA AGT TTA CAC CAA CCA CAA GGA 115

$\ldots \ldots$... Met Ile Ile Asn His Asn Leu Pro

TGT GGG CGG AAA ACG CAT TTC AAG GAG GAT GTT TTA ATG ATT ATC AAT CAC AAT TTA CCA 175

Ala Met Asn Ala His Arg Asn Met Gly Ile Asn Leu Asn Gln Gly Gln Lys Ala Met Glu

GCA ATG AAT GCG CAT CGT AAC ATG GGT ATC AAT CTT AAC CAA GGT CAA AAA GCG ATG GAG 235

Lys Leu Ser Ser Gly Leu Arg Ile Asn Arg Ala Gly Asp Asp Ala Ala Gly Leu Ala Ile

AAG CTT TCT TCA GGT CTT CGC ATT AAC CGT GCA GGA GAC GAT GCT GCA GGT CTT GCC ATC 295 HindIII

Ser Glu Lys Met Arg Ala Gln Ile Arg Gly Leu Asp Gln Ala Ser Arg Asn Ser Gin Asp TCT GAA AAA ATG CGT GCG CAA ATC CGT GGT TTG GAT CAA GCG TCT CGT AAC TCA CAA GAC 355

Gly Ile Ser Leu Ile Gln Thr Ala Glu Gly Ala Leu Asp Glu Val His Ser Ile Leu Gln

GGT ATT TCG TTA ATT CAA ACA GCT GAA GGT GCG CTT GAT GAA GTA CAT TCT ATT CTT CAA 415

Arg Met Arg Glu Leu Ala Val Gln Ser Ser Asn Glu Thr Asn Val Glu Gln Asp Gln Ala CGT ATG CGT GAG CTA GCG GTT CAA TCT TCG AAC GAA ACG AAT GTT GAG CAA GAT CAA GCA 475

Ala Leu Asn Asp Glu Phe Gln Gln Leu Val Glu Glu Ile Glu Arg Ile Lys Asp Thr Thr GCT CTT AAC GAT GAA TTC CAA CAA TTA GTT GAG GAA ATT GAA AGA ATC AAA GAT ACA ACT 535

Gln Phe Asn Thr Gln Lys Leu Leu Asp Asp Thr Val Asp Thr Val Gln Leu Gln Val Gly CAA TTT AAT ACG CAA AAA TTA CTC GAT GAT ACA GTA GAT ACT GTA CAA CTT CAA GTT GGT 595

Ala Asn Ser Gly Glu Leu Ile Glu Leu Asp Leu Thr Lys Val Asp Leu Ser Ala Ile His GCT AAT TCT GGT GAA TTA ATT GAA CTT GAT TTA ACA AAA GTT GAT TTA TCA GCT ATC CAT 655

Thr Ala Leu Ala Ala Glu Asp Ile Thr Asp His Thr Asn Ala Gln Ser Ala Ile Asp Ala ACA GCT TTG GCG GCT GAG GAT ATT ACT GAC CAC ACT AAT GCA CAA TCA GCT ATT GAC GCT 715

Ile Asp Glu Gln Leu Lys Ala Val Ser Glu Gly Arg Ser Tyr Leu Gly Ala Met Gln Asn ATT GAT GAG CAA TTA AAA GCT GTT TCA GAA GGT CGC TCT TAC CTA GGA GCT ATG CAA AAC 775

Arg Leu Glu His Thr Ile Lys Asn Leu Asp Asn Ala Ser Glu Asn Leu Gln Ala Ala Glu CGC CTA GAG CAT ACA ATC AAA AAC CTT GAT AAT GCT TCT GAA AAC CTT CAA GCT GCT GAG 835

Ser Arg Ile Arg Asp Val Asp Met Ala Lys Glu Met Met Glu phe Thr Arg Thr Asn Ile TCT CGT ATC CGT GAC GTA GAC ATG GCG AAA GAA ATG ATG GAG TTC ACA AGA ACA AAC ATC 895 AcCl

Leu Asn Gin Ala Ser Gln Ala Met Leu Ala Gin Ala Asn Gln Gin Pro Gin Ala Val Leu

TTA AAC CAA GCG TCT CAA GCG ATG CTT GCT CAA GCA AAC CAA CAG CCA CAA GCT GTA TTA 955

GIn Leu Leu Arg TER

CAA TTA CTT CGT TAA TTT GCT TCC ATT TAA AGA TCT GGA TTT ATT CCA GGT CTT TTT TAT 1015

TTT CCG CTC AAC CGT TAC TTT GCT GAT AGG TTG TTA AAG TTT AGG AAT

1062

Fig. 6. Nucleotide sequence of the alkalophilic Bacillus sp. C-125 hag gene and corresponding amino acid sequence. The nucleotides underlined represent the putative promoter regions. The nucleotides overlaid with dots represent a potential ribosome-binding site. The nucleotides overlined may form a hair-pin loop structure which results in termination of transcription.

subtilis (LaVallie \& Stahl, 1989; Mirel \& Chamberlin, 1989 ) and $R$. cecicola (Martin \& Savage, 1988) flagellins. The alignment with the $B$. subtilis flagellin sequence is shown in Fig. 7. Whereas the $\mathrm{N}$-terminal region (amino acids 1-96) and C-terminal region (amino acids 200-272) show 74 and $82 \%$ identity, respectively, to the comparable regions in the $B$. subtilis flagellin, the central region (amino acids $97-199$ ) shows only $32 \%$ identity. Such a pattern of similarity in $\mathrm{N}$ - and $\mathrm{C}$-terminal regions and dissimilarity in the central regions has been observed for 

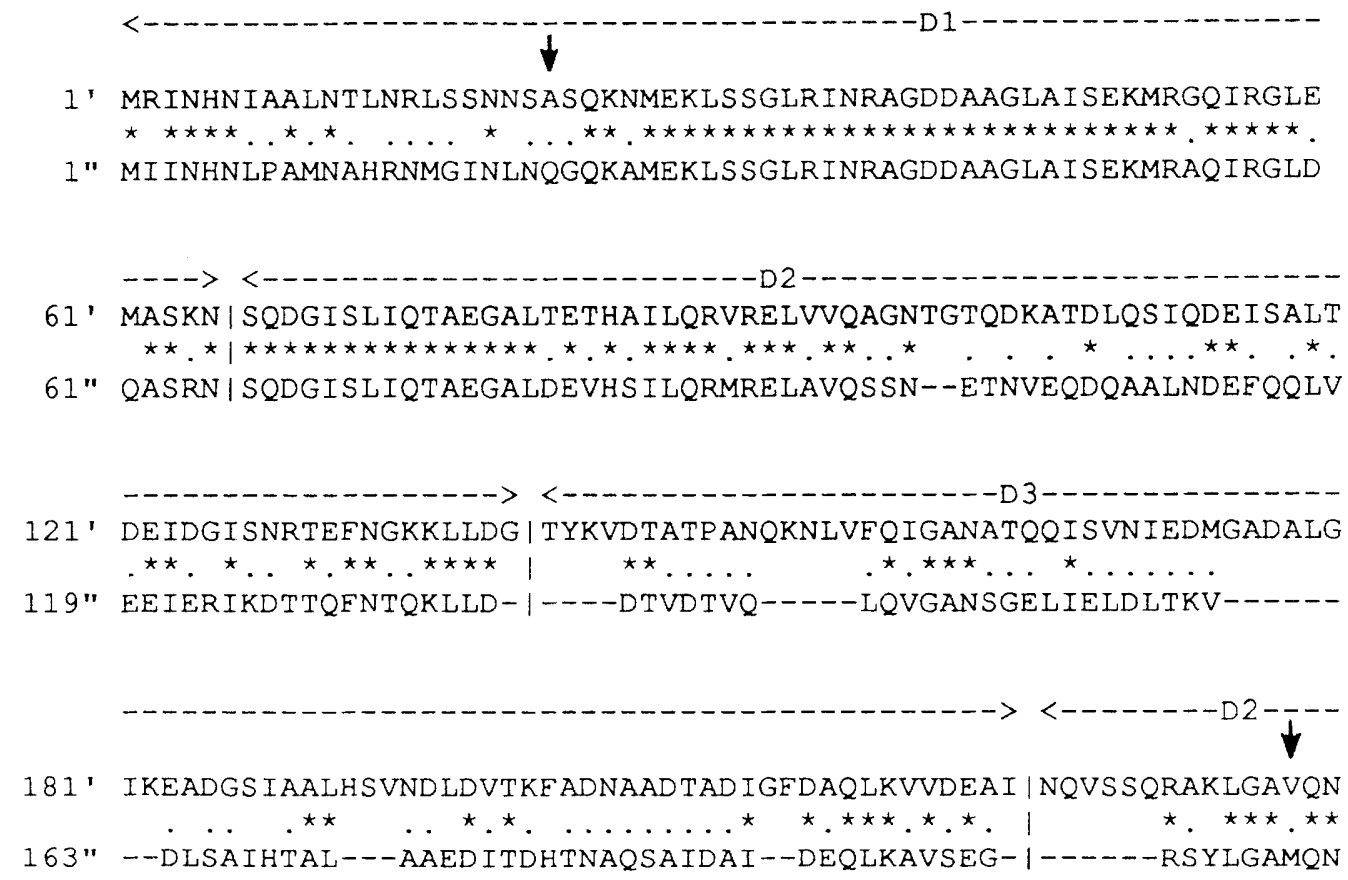

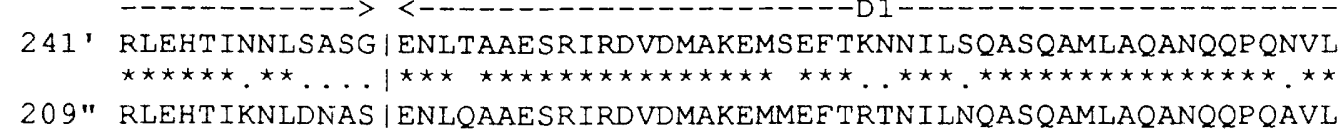

$$
\begin{aligned}
& 301 \cdot \begin{array}{l}
-->> \\
\text { QLLR } \\
\star \star \star \star
\end{array} \\
& \text { 269" QLLR }
\end{aligned}
$$

Fig. 7. Alignment of the alkalophilic Bacillus sp. C-125 (lower) and the B. subtilis (upper) flagellin amino acid sequences. Identical amino acids and homologous amino acids are highlighted by asterisks and dots, respectively. Amino acids conserved in neutrophilic flagellins but altered in the alkalophilic flagellin are indicated by the vertical arrows. Domains 1, 2 and 3 [as proposed by Namba $e t$ al. (1989) for the $S$. typhimurium flagellin] are shown.

other sequenced flagellins (Joys, 1985; Wei \& Joys, 1985; Martin \& Savage, 1988; LaVallie \& Stahl, 1989).

It has been proposed that the conserved regions of flagellin play an important structural role in the flagellar filament. Homma et al. (1987) proposed a hairpin loop structure for the $S$. typhimurium flagellin in which both the $\mathrm{N}$ - and the $\mathrm{C}$-terminus point into the interior of the filament. This model is supported by the findings of Namba et al. (1989), who have assigned the primary amino acid sequence of $S$. typhimurium flagellin to three domains identified from electron-density maps. Domain 1 , the innermost domain, and domain 2 , the middle domain, appear to be made up of amino acids from the $\mathrm{N}$ - and $\mathrm{C}$-terminal regions, whereas domain 3, situated on the filament surface, contains the highly variable, central sequence of amino acids.
In addition to the apparent structural role of the $\mathrm{N}$ and C-termini, these regions are believed to be involved in filament assembly (Joys, 1985; Wei \& Joys, 1985; Trachtenberg \& DeRosier, 1988). Moreover, the extreme C-terminal region of the $B$. subtilis flagellin has been demonstrated to be involved in its transport from the cytoplasm to the outer membrane (LaVallie \& Stahl, 1989).

The central, variable region of the flagellin peptide has not been implicated with any structural or functional properties of the protein. In the structures proposed by Homma et al. (1987) and Namba et al. (1989) it is the central portion that forms the outer surface of the flagellin filament, and thus, this portion is exposed to the outer environment of the cell. For Bacillus sp. C-125 the environment is alkaline and so the central portion of the 
flagellin, on the outer surface of the flagellar filament, is likely to require special adaptations to these alkaline conditions. This may explain the very low level of homology observed between the central regions of the alkalophilic Bacillus sp. C-125 and B. subtilis flagellins.

Decreased amounts of acidic and/or basic amino acids have been observed in some alkalophilic proteins (Guffanti \& Eisenstein, 1983; Van der Laan et al., 1991). The overall amino acid content of the alkalophilic Bacillus sp. C-125 does not appear to be significantly different from that of the $B$. subtilis flagellin (Table 1). However, the alkalophilic Bacillus sp. C-125 domain 3 does appear to have fewer charged amino acids than the equivalent region in the B. subtilis flagellin (Fig. 7). Thus, it seems that, if we confine the comparison to regions that are presumed to be exposed to alkaline conditions, the low content of basic or acidic amino acids observed in other alkalophilic proteins (Guffanti \& Eisenstein, 1983; Van der Laan et al., 1991) can also be observed in the alkalophilic Bacillus sp. C-125 flagellin.

Due to the high level of variation among the flagellin central regions it is difficult to pinpoint and investigate possible changes in the alkalophilic Bacillus sp. C-125 flagellin that may contribute to its adaptation to alkaline conditions. However, the conserved $\mathrm{N}$ - and $\mathrm{C}$-terminal regions (domains 1 and 2) are also likely to show adaptations to alkalinity since these, although not situated on the outer surface of the flagellum, may, for example, be exposed during the assembly process. Moreover, Kanto et al. (1991) have shown that amino acids responsible for flagellin shape are located in the terminal regions of the $S$. typhimurium flagellin. A comparison of the $\mathrm{N}$ - and $\mathrm{C}$-terminal regions revealed that only two amino acids, an Ala (Gln 22 of Bacillus sp. C-125 flagellin, domain 1) and a Val (Met 206 of Bacillus sp. C-125 flagellin, domain 2) (Fig. 7), conserved in all four neutrophilic bacterial flagellins are different in the alkalophilic Bacillus sp. C-125 flagellin. Site-directed mutagenesis work is currently in progress to investigate whether these changes contribute to the alkaline adaptation of alkalophilic Bacillus sp. C-125 flagellin.

We wish to thank Ms M. Yamamoto for carrying out the $\mathrm{N}$-terminal sequence determination. This work was partially supported by a grant for the Biodesign Research Program from RIKEN to T. Kudo.

\section{References}

Asakura, S., Eguchi, G. \& IINo, T. (1964). Reconstruction of bacterial flagella. Journal of Molecular Biology 10, 42-56.

BlaIR, D. F. \& BeRG, H. C. (1990). The motA protein of $E$. coli is a proton-conducting component of the flagellar motor. Cell 60, 439449.

Dean, G. E., Macnab, R. M., Stader, J., Matsumura, P. \& Burks, C. (1984). Gene sequence and predicted amino acid sequence of the mot $A$ protein, a membrane-associated protein required for flagellar rotation in Escherichia coli. Journal of Bacteriology 159, 991-999.

Edman, P. \& Henschen, A. (1975). Sequence determination. In Protein Sequence Determination, 2nd edn, pp. 232-279. Edited by S. B. Needleman. Berlin: Springer-Verlag.

Gill, P. R. \& AGabian, N. (1983). The nucleotide sequence of the $M_{\mathrm{r}}=28,000$ flagellin gene of Caulobacter crescentus. Journal of Biological Chemistry 258, 7395-7401.

Guffanti, A. A. \& Eisenstein, H. C. (1983). Purification and characterization of flagella from the alkalophilic Bacillus firmus RAB. Journal of General Microbiology 129, 3239-3242.

Hirota, N., Kitada, M. \& Imae, Y. (1981). Flagellar motors of alkalophilic Bacillus are powered by an electrochemical potential gradient of $\mathrm{Na}^{+}$. FEBS Letters 132, 278-280.

Homma, M., Fujta, H., Tamaguchi, S. \& IINo, T. (1987). Regions of Salmonella typhimurium flagellin essential for its polymerisation and excretion. Journal of Bacteriology 169, 291-296.

Honda, H., Kudo, T., IkURA, Y. \& HorikoshI, K. (1985). Two kinds of xylanases of alkalophilic Bacillus sp. No. C-125. Canadian Journal of Microbiology 31, 538-542.

IINO, T. (1977). Genetics of structure and functions of bacterial flagella. Annual Review of Genetics 11, 161-182.

Joys, T. M. (1985). The covalent structure of the phase-1 flagellar filament protein of Salmonella typhimurium and its comparisons with other flagellins. Journal of Biological Chemistry 260, 15758-15761.

KAMIYA, R. \& ASAKURA, S. (1976). Helical transformations of Salmonella flagella in vitro. Journal of Molecular Biology 106, 167-186.

Kanto, S., OKINo, H. \& Aizawa, S.-I. (1991). Amino acids responsible for flagellar shape are distributed in terminal regions of flagellin. Journal of Molecular Biology 219, 471-480.

Kudo, T., Hino, M., Kitada, M. \& Horikoshi, K. (1990). DNA sequences required for the alkalophily of Bacillus sp. C-125 are located close together on its chromosomal DNA. Journal of Bacteriology 172, 7282-7283.

Kuwajima, G., Asaka, J., Fujiwara, T., Fujiwara, T., Node, K. \& KONDO, E. (1986). Nucleotide sequence of the hag gene encoding flagellin of Escherichia coli. Journal of Bacteriology 168, 1479-1483.

LAEMML1, U. K. (1970). Cleavage of structural proteins during the assembly of the head of bacteriophage T4. Nature, London 227, $680-$ 685.

LaVallie, E. R. \& Stahl, M. L. (1989). Cloning of the flagellin gene from Bacillus subtilis and complementation studies of an in vitroderived deletion mutation. Journal of Bacteriology 171, 3085-3094.

Logan, S. M., HarRIS, L. A. \& TRUST, T. J. (1987). Isolation and characterization of Campylobacter flagellins. Journal of Bacteriology 169, 5072-5077

MaCnAB, R. M. \& AizawA, S.-I. (1984). Bacterial motility and the bacterial flagellar motor. Annual Review of Biophysics and Bioengineering 13, 51-83.

Martin, J. H. \& Savage, D. C. (1988). Cloning, nucleotide sequence, and taxonomic implications of the flagellin gene of Roseburia cecicola. Journal of Bacteriology 170, 2612-2617.

MartineZ, R. J. (1963). A method for the purification of bacterial flagella by ion exchange chromatography. Journal of General Microbiology 33, 115-120.

Mirel, D. B. \& Chamberlin, M. J. (1989). The Bacillus subtilis flagellin gene ( $h a g$ ) is transcribed by the $\sigma^{28}$ form of RNA polymerase. Journal of Bacteriology 171, 3095-3101.

NAmba, K., Yamashita, I. \& Vonderviszt, F. (1989). Structure of the core and central channel of bacterial flagella. Nature, London 342 , 648-654.

Ridgeway, H. F., Silverman, M. \& Simon, M. I. (1977). Localization of proteins controlling motility and chemotaxis in Escherichia coli. Journal of Bacteriology 132, 657-665.

SAITO, H. \& MiURA, K. (1963). Preparation of transforming DNA by phenol treatment. Biochimica et Biophysica Acta 72, 619-629.

SambroOK, J., FrITSCH, E. F. \& Maniatis, T. (1989). Molecular Cloning, 2nd edn. Cold Spring Harbor, NY: Cold Spring Harbor Laboratory.

Sanger, F., Nicklen, S. \& Coulson, A. R. (1977). DNA sequencing with chain-terminating inhibitors. Proceedings of the National Academy of Sciences of the United States of America 74, 5463-5467. 
Silverman, M. \& Simon, M. (1977). Bacterial flagella. Annual Review of Microbiology 31, 397-419.

Sugiyama, S., Cragoe, E. J. \& Imae, Y. (1988). Amiloride, a specific inhibitor for the $\mathrm{Na}^{+}$-driven flagellar motors of alkalophilic Bacillus. Journal of Biological Chemistry 263, 8215-8219.

TRACHTEnBerG, S. \& DeRosier, D. J. (1988). Three-dimensional reconstruction of the flagellar filament of Caulobacter crescentus. Journal of Molecular Biology 202, 787-808.
Van der LaAn, J. C., Gerritse, G., Mulleners, L. J. S. M., Van Der HOEK, R. A. C. \& QUAX, W. J. (1991). Cloning, characterization and multiple chromosomal integration of a Bacillus alkaline protease gene. Applied and Environmental Microbiology 57, 901-909.

WEI, L. \& JoYs, T. M. (1985). Covalent structure of three phase-1 flagellar filament proteins of Salmonella. Journal of Molecular Biology 186, 791-803. 